\title{
CRIMINAL LAW - CRIMINAL SEXUAL PSYCHOPATH- DEFINITION - WHETHER FORCE IS NECESSARY
}

JoHn W. McCl.ung, Third Year Law

In 1947, Parliament adopted legislation designed to cope with the enigma of the criminologist, the habitual criminal. Isolation of the offender via the indeterminate sentence was the solution attempted. The same session passed companion provisions, now embodied in the Criminal Code', whereby the court may in the proper case, deem an accused a criminal sexual psychopath and incarcerate him for an indeterminate period. To the best of the writer's knowledge, these latter provisions are unique in the British Commonwealth.

While judicial review of the preventive detention of habitual criminals has been extensive, little authority was available on the sections providing for the indeterminate sentence of the criminal sexual psychopath until the recent decision of the Supreme Court of Canada in The Queen v. Neil [1957] S.C.R. 685. Although the sections had been invoked frequently, apparently only three cases ${ }^{3}$ reached the law reports. None of them provided much in the way of guidance for future cases regarding the elements of "criminal sexual psychopath". In Neil however, the definitive section of the code, s.659(b), underwent an exhaustive and analytical examination by the members of the court and their observations will no doubt fill the ten year vacuum.

This section defines a criminal sexual psychopath as

a person who, by a course of misconduct in sexual matters has shown a lack of power to control his sexual impulses and who as a result is likely to attack or otherwise inflict injury, pain or other evil on any person.

This comment examines one of the interpretations arrived at in relation to the underlying but often baffling intention of the legislator".

The respondent, Sidney Keith Neil, was convicted on two charges of gross indecency and pursuant to s.661 (1) ${ }^{5}$ the trial judge, Boyd McBride J, heard

'Statutes of Canada, 1953.54, e.51, hereinafter called the code.

zHansard, House of Commons Debates 1953.54 vol. 111 p. 2898 . Up to 1954 sixteen individuals had been sentenced under the provisions. None had been released by executive intervention pursuant to 3.666 of the Criminal Code.

${ }_{R}$ R. v. Tilley (1952) 104 C.C.C. 315,196 C.C.C. 42 (Appeal).

R. v. Hoye (1953) 107 C.C.C. 59.

R.v. Tousignant [1957] O.W.N. 573.

The reader will find an excellent discussion and criticism of the value of similar statutes in force in twenty-one U.S. jurisdictions by Paul W. Tappan at p.500 of Sexual Offences Vol. IX of English Studies of Criminal Science. That aspect is beyond the scope of this comment. Parliament has spoken. We are concerned with what was said. See also, generally: DeGrazia, Crime Without Punishment: A Psychiatric Conundrum, 52 Columbia L. Rev. 746 (1952), Radzinowicz, The Persistent Offender, The Modern Approach 10 Criminal Law, p. 162.

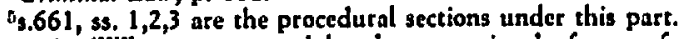

ss 1. (Where an accused has been convicted of any of the moral offences included under Criminal Code Sections 136, 138, 141, 147, 148 or 149, or attempts thereto) the Court may upon application before passing sentence, heas evidence as to whether the accused is a criminal sexual psychopath.

ss 2. (Any application must include the evidence of two psychiatrists, one of whom nominated by the Attorney-General).

ss 3. - empowers, upon conviction, the imposition of the indeterminate sentence. 
evidence as to whether the accused was an individual of the type contemplated by s. 659 (b). The accused appealed from the affirmative finding of Boyd McBride J. and the Appellate Division of the Supreme Court of Alberta (Johnson J.A. dubitante) quashed the conviction "on the grounds that the Crown has failed to bring the evidence of the psychiatrists within the definition of a criminal sexual psychopath". The subsequent appeal of the Crown was dismissed by the Supreme Court of Canada (Locke and Taschereau JJ. dissenting).

As $s .659$ (b) is designed to forecast probable future conduct from previous misconduct, Neil's past was carefully examined by the court (Kerwin C.J. Cartwright, Locke, Rand, Taschereau, Abbott and Nolan JJ.), through Cartwright J. Perversity was admitted to be part of the accused's life at an early age, as well as incidents taking place in 1938, 1954, 1955 and 1956, although as Cartwright J. pointed out, his own testimony might infer that there were other similar acts. Nevertheless the accused had no criminal record except, of course, the conviction referred to above which initiated the Crown's application.

While the deviations in question were somewhat varied, the accused never resorted to force to achieve his ends and upon any sign of resentment or disdain from his partner he immediately desisted.

Per Cartwright J:

On the cvidence there is no room for the suggestion that the respondent has ever attacked or is ever likely to attack anyone and in the course of his full and helpful argument Mr. Frawley disclaimed any suggestion that the respondent had used, or was likely to use, anything in the nature of force or compulsion to bring about the gratification of his abnormal desires. ${ }^{8}$

This fact was of no small importance in the judgments which followed.

The court concerned itself with two interpretive problems in 5.659 (b), (1) What is a "lack of power to control" sexual impulses and (2) do the words "otherwise inflict" connote elements of coercion, force or compulsion. However in the writer's submission the ratio decidendi of the case was that the evidence did not indicate that the accused "is likely" to repeat his previous conduct and that the remarks upon the other elements of the definition were obiter dicta and should be regarded in that light.

Kerwin C.J. (with whom Abbott J. concurred) as well as Cartwright J. found that the evidence did not establish the likelihood of the resumption of the accused's immoral conduct. Locke J. (Taschereau J. concurring), in his dissenting judgment, held that a perverted propensity was too clearly illustrated in the past to deny the probability of future recurrence. Rand J., who concurred in the dismissal of the appeal, preferred to base his judgment on an interpretation of the words "lack of power to control" and made no reference to the question of likelihood of repetition.

Chief Justice Kerwin and Abbott J. agreed that the statutory words "inflict injury, pain or other evil" imported no criterion of duress or coercion.

-[1957] S.C.R. 687-Neither the trial nor Court of Appeal judgment was reported.

'Nolan J., died before judgment was delivered.

Bp. 698. 
Parliament has distinguished 'attack' which indicates force, from inflicting injury, pain or other evil. One may inflict, that is, cause another to suffer or incur, something that is inherently evil by persuading him without the use of force to commit the act, the effect of which may remain with him for many years. I am unable to restrict the meaning of the words Parliament has chosen to carry out its intention to those cases where coercion is used.

This view was not shared by Cartwright $J$, who in the course of his judgment said:

To persuade a youth to participate in acts of gross indecency is in itself a crime and there is no need to expatiate on the heinousness of such conduct; but the person who so persuades a youth is causing him to do evil rather than inflicting evil upon him. The primary meanings of the word "inflict", given in the Shorter Oxford Dictionary are "to lay on as a stroke, blow or wound; to impose; to cause to be borne". In my opinion neither of the verbs "to attack" or "to inflict" is npt to describe conduct, however evil in its ultimate putpose, which contains no element of force, violence or coercion but consists solely of temptation and persuasion.

I have reached this conclusion on the construction of the words of the definition, but it appears to me to be strengthened by a consideration of the evil which the enactment of the sections dealing with criminal sexual psycopaths was intended to remedy. The purpose of the enactment appears, from the related sections read as a whole, to be to protect persons from becoming the victims of those whose lack of power to control their sexual impulses renders them a source of danger; and the danger envisaged is, I think, that of coercive conduct resulting in the active infliction of pain, injury or other evil on the victim, not merely the persuading or seducing of another to participate in sexual misconduct. This view is also, in my opinion supported by a consideration of the drastic nature of the preventive measure provided, that is, incarceration which may continue for life. ${ }^{10}$

The two views are diametric opposites and their reconciliation is hopeless. It is submitted that, on the present wording of the section, the latter view is preferable and should be followed until Parliament may see fit to clarify the matter.

The problem is, of course, how far has the Legislature of fered the liberty of the subject at the altar of public order and safety. The evil sought to be prevented is a real, and especially from a parental standpoint, a most odious one. It is true that the twentieh century has looked compassionately upon those suffering from psychopathic disorders - this, no doubt, is due to the impact upon thought set in motion by Freud and his followers. Tolerance and understanding are, to be sure, a commendable foundation for the great progressive strides made in most aspects of the study of human motivation. Nonetheless it is understandable that such is not so paramount in the criminal law whose primary design is the prevention of conduct detrimental to the state. While simultaneous rehabilitation of the criminal is most desirable, we have not, as yet, arrived at that plateau and because of this the first duty of the legislator and the lawyer following his instructions is the protection of the innocent. Reformation of the offender can only be secondary while Canada's prisons and reformatories lack proper facilities.

Even with the foregoing in mind, while the course of conduet sought to be excluded by 5.659 (b) is grave, the sanction, preventive detention which may last for life, is similarly fearful. When proceeding under this section can the fact that an accused has conducted himself without recourse to force be held to be of no importance?

The Chief Justice's view, that absence of coercion is not a mitigating 
feature, is not untouched by policy considerations. The well-being of the young is to be preserved regardless of the manner in which it is jeopardized. The passage "to commit the act, the effect of which may remain with him for years"1 indicates a concern not only for the present moral outrage but for the scar or mental block, sometimes indelible, left upon the mind of the abused child. But is it not reasonable to assume that this effect is less likely to be brought about when force or coercion was not employed? Can it be fairly said that the use of force is irrelevant when the question is posed as to which individual is the greater menace? Much of our criminal jurisprudence reflects a distinction between antisocial conduct effected by the use of force and that which is not. Penal provisions often recognize the difference. It is submitted that a distinction in s.659(b) was intended and may be drawn.

In R. v. Clarence ${ }^{12}$ Stephen J. was faced with the same difficulty as in Neil. Does the verb "inflict" connote force? In that case, the accused husband had contracted a venereal disease, which he transmitted to his wife and was charged under a statute reading "Whoever shall unlawfully and maliciously wound or inflict any grevious bodily harm upon any person, either with or without any weapon or instrument ... (shall be guilty of a punishable of fense)". Said his Lordship:

But is there an infliction of bodily harm cither with or without any weapon or instrument? I think there is not for the following reasons. The word appears to me to mean the direct causing of some grievous injury to the body itself with a weapon as by a cut with a knife or without a weapon, as by a blow with a fist or by pushing a person down .... I think the words imply assault and battery. . . 1s

His Lordship later observed, in passing, that "inflict" was derived from the latin "infligo" for which a popular lexicon of the day gave six equivalents all meaning "to strike". Admittedly, a previous interpretation of a word is of little assistance by way of precedent but it may be pointed out that in Clarence also the word "inflict" was found in a criminal statute and, as in 5.659 (b), it was preceded by words clearly connoting force followed by the disjunctive "or". Moreover, any opinion of so eminent a judge as Stephen J. is not without some persuasive value.

In conclusion, while far from advocating that leniency be the rule in the consideration of these matters, the writer submits that only an exact and strict construction of Parliament's words should be employed, in view of the punish. ment provided. It is well remembered that

. . a stature, particularly the Criminal Code, is not a place for the nuances and delicate brushes of meaning that embroider our literature. A criminal statute aimed to deprive people of their liberty for indeterminate periods even perhaps to the extent of life imprison. ment, must clothe itself with precision. ${ }^{11}$

The problem is one which could be resolved by a few strokes of the legislative pen and it is hoped that this will be done without undue delay.

"Supra, footnote 8.

1222 Q. B. D. (1888) 23.

${ }^{38}$ p. 41, supra, footnote 11.

${ }^{11}$ O'Halloran J.A., R. v. Robinson (or Robertson) [1950] 2 W.W.R. 1265 at 1265 . The Supreme Court of Canada [1951] S.C.R. S22, on appeal, decided that the statute in question was precisely clothed and not exposed to the rigorous elements of ambiguity. 